\title{
Immunoglobulin A and $M$ Levels in Premature Infants with Gastroenteritis
}

\author{
P. PANAYOTOU, C. PAPADATOS, G. PAPAEVANGELOU, D. AlEXIOU, \\ A. SKARDOUTSOU, and E. KOUREA \\ From the 1st Obstetrical and Gynaecological Clinic of the University of Athens, Neonatal Department; \\ and the Department of Hygiene and Epidemiology of the University of Athens
}

Panayotou, P., Papadatos, C., Papaevangelou, G., Alexiou, D., Skardoutsou, A., and Kourea, E. (1971). Archives of Disease in Childhood, 46, 671. Immunoglobulin $A$ and $M$ levels in premature infants with gastroenteritis. Eleven premature babies with an infection of the gastrointestinal tract were followed from birth up to the first month of life in an attempt to correlate the effect of acute localized infections of the gut to IgA and IgM immunoglobulin synthesis. The results were compared to those of 17 prematures comparable in birthweight and gestational age with no clinical or bacteriological evidence of an intestinal infection.

There was a significant increase of serum IgA and a slight but not significant increase of IgM level in infected babies as compared to the healthy group of prematures. It is suggested that micro-organisms causing localized infections of the gastrointestinal tract stimulate immunoglobulin A producing sites of the intestinal wall. This results in rapid production of secretory antibody. In the course of this localized infection, replication of bacteria in the lymphoid tissue of the intestinal wall stimulate immunologically competent cells in direct proximity to the alimentary tract, causing increased serum IgA levels.

The presence of immunoglobulin $A$ and $M$ in the umbilical cord blood of the newborn is due either to active synthesis by the fetus as a result of congenital infections (McCracken and Shinefield, 1965; Stiehm, Ammann, and Cherry, 1966) or to leakage of maternal blood into the fetal circulation.

After birth, isolating a newborn in a germ-free environment will inhibit the development of immunoglobulins (Olson and Wostman, 1966; Kim, Bradley, and Watson, 1966). Exposure, however, of germ-free newborn experimental animals to environmental antigens will induce immunoglobulin synthesis and maturation of lymphoid tissue cells (Wostman and Gordon, 1960). These observations have led Sterzl and Silverstein (1967) to suggest that immunoglobulin synthesis is a result of antigenic stimulation in the gastrointestinal and respiratory tracts.

Though the role of serum immunoglubin A has not been fully elucidated, the secretory form which differs from serum IgA both in size, composition, and resistance to enzymatic splitting (Tomasi

Received 5 April 1971. and Galvanico, 1968) has recently received attention as a significant factor in the prevention of human disease.

The purpose of this study is to present evidence that bacterial pathogens, acquired soon after birth by the gastrointestinal tract of the premature baby, initiate rapid immunoglobulin A synthesis.

\section{Material and Methods}

Data for this study were obtained in the summer of 1969, when an unusually high number of cases of gastroenteritis occurred in a ward of the premature Nursery of 'Alexandra' Maternity Hospital.

It was then decided to study for a period of a month all premature babies (gestational age 28-35 weeks) with a birthweight of 1000-2000 g. All newborns received routine care in the premature nursery during the follow-up period. They were under continuous supervision by one of us (D.A.), thus assuring comparable care. Routine stool cultures were done every 10 days and occasional blood cultures were drawn on the severely infected prematures. Final diagnosis of a gastrointestinal infection was established by clinical and laboratory findings. On the basis of clinical and laboratory evidence, 17 of these newborns were con- 
sidered well, while 11 developed a bacteriologically confirmed gastroenteritis requiring parenteral fluids and antibiotic therapy.

Blood samples were drawn aseptically at birth (cord blood) and thereafter every 10 days. Sera were separated and stored aseptically at $-20^{\circ} \mathrm{C}$ until tested. Quantitative estimates of immunoglobulins were done by the single gel diffusion technique of Mancini, Carbonara, and Heremans (1965).

Pertinent characteristics of the two groups of babies are tabulated in Table $I$. The two groups showed no significant difference in their mean birthweight $(t=$ $0 \cdot 7, P>0 \cdot 1)$ or gestational age $(t=0.8, P>0.1)$.

TABLE I

Characteristics of Studied Groups of Premature Babies

\begin{tabular}{l|c|c|c}
\hline \multicolumn{1}{c|}{ Group } & $\begin{array}{c}\text { No. of } \\
\text { Infants }\end{array}$ & $\begin{array}{c}\text { Weight Range } \\
(\mathrm{g})\end{array}$ & $\begin{array}{c}\text { Gestation } \\
\text { (wk) }\end{array}$ \\
\hline $\begin{array}{l}\text { Healthy } \\
\text { Diarrhoea }\end{array}$ & 17 & $1020-1650$ & $28-34$ \\
& 11 & $1050-1900$ & $28-35$ \\
\hline
\end{tabular}

\section{Results}

Data from 17 premature infants free of any suspicion of infection were compared with data from 11 prematures with clinical and bacteriological evidence of a gut infection. These are presented in Tables II and III.

IgA and IgM levels in healthy infants. As shown in Table II, cord sera from 4 infants had detectable IgA levels $(<2 \mathrm{mg} / 100 \mathrm{ml})$, while in
13 babies IgA was undetectable in all specimens. IgA levels increased gradually with some infants showing earlier rises (Cases 2, 3, 8, 10, 11, 14, 16, 17), while in others (Cases 5, 6, 7, 9, 12, 13, and 15) the 10-day immunoglobulin A estimation remained at the zero value. Mean levels at age 10, 20, and 30 days were $4 \cdot 8,15 \cdot 6$, and $24 \cdot 4 \mathrm{mg} / 100 \mathrm{ml}$, respectively.

All cord sera had IgM. One premature (Case 3) had a raised level at birth. This remained high in all subsequent determinations. This baby was normal in the nursery and no evidence of maternal disease could be obtained. The mean level of IgM was $12 \cdot 1 \mathrm{mg} / 100 \mathrm{ml}$ at birth, while at age 10,20 , and 30 days it was $36 \cdot 3,48 \cdot 6$, and $37 \cdot 9$ $\mathrm{mg} / 100 \mathrm{ml}$, respectively. In 10 of the 17 babies the 30-day specimen showed a decrease of $\operatorname{IgM}$ compared with the 20-day specimen.

IgA and IgM levels in infants with gastrointestinal tract infection. Cord sera from 5 prematures had detectable IgA levels $(<2 \mathrm{mg} /$ $100 \mathrm{ml}$ ) while in 5 babies this immunoglobulin was undetectable (Table III). One infant (Case 1) had high IgA levels at birth as well as high IgM values. Diarrhoea in this baby developed at the age of 10 days and was considered clinically moderate.

In 9 infants the infectious process was diagnosed at age 5 to 12 days, while in 2 diarrhoea developed at the age of 28 and 19 days respectively (Cases 5 and 10).

TABLE II

Healthy Group: Immunoglobulin $A$ and $M$ Levels in Healthy Group of Prematures

\begin{tabular}{|c|c|c|c|c|c|c|c|c|c|}
\hline \multirow{3}{*}{$\begin{array}{l}\text { Case } \\
\text { No. }\end{array}$} & \multirow{3}{*}{$\begin{array}{l}\text { Birthweight } \\
\quad(\mathrm{g})\end{array}$} & \multicolumn{4}{|c|}{ Immunoglobulin A (mg/100 ml) } & \multicolumn{4}{|c|}{ Immunoglobulin $\mathrm{M}(\mathrm{mg} / 100 \mathrm{ml})$} \\
\hline & & \multirow{2}{*}{$\begin{array}{l}\text { Cord } \\
\text { Blood }\end{array}$} & \multicolumn{3}{|c|}{ Age (dy) } & \multirow{2}{*}{$\begin{array}{l}\text { Cord } \\
\text { Blood }\end{array}$} & \multicolumn{3}{|c|}{ Age (dy) } \\
\hline & & & 10 & 20 & 30 & & 10 & 20 & 30 \\
\hline $\begin{array}{r}1 \\
2 \\
3 \\
4 \\
5 \\
6 \\
7 \\
8 \\
9 \\
10 \\
11 \\
12 \\
13 \\
14 \\
15 \\
16 \\
17\end{array}$ & $\begin{array}{l}1430 \\
1500 \\
1500 \\
1020 \\
1400 \\
1430 \\
1350 \\
1550 \\
1650 \\
1570 \\
1480 \\
1600 \\
1510 \\
1400 \\
1500 \\
1480 \\
1430\end{array}$ & $\begin{array}{r}<2 \\
<2 \\
<2 \\
<2 \\
0 \\
0 \\
0 \\
0 \\
0 \\
0 \\
0 \\
0 \\
0 \\
0 \\
0 \\
0 \\
0\end{array}$ & $\begin{array}{c}2 \\
5 \cdot 4 \\
8 \cdot 8 \\
<2 \\
0 \\
0 \\
0 \\
9 \\
0 \\
13 \\
15 \\
0 \\
0 \\
8 \\
0 \\
8 \\
11\end{array}$ & $\begin{array}{c}13 \\
9 \cdot 4 \\
10 \\
13 \\
12 \cdot 5 \\
20 \\
13 \\
13 \\
16 \\
31 \\
22 \\
18 \\
0 \\
15 \\
15 \\
13 \\
31\end{array}$ & $\begin{array}{l}31 \\
12 \\
13 \\
27 \\
18 \\
53 \\
31 \\
15 \\
16 \\
36 \\
25 \\
25 \\
0 \\
26 \\
33 \\
25 \\
29\end{array}$ & $\begin{array}{c}10 \cdot 5 \\
8 \cdot 8 \\
39 \\
7 \\
13 \\
18 \\
8 \\
7 \\
9 \\
7 \cdot 7 \\
7 \\
15 \\
10 \\
8 \\
\frac{13}{13} \\
13\end{array}$ & $\begin{array}{l}25 \\
35 \\
84 \\
21 \\
35 \\
80 \\
15 \\
25 \\
28 \\
45 \\
27 \\
54 \\
14 \\
25 \\
13 \\
22 \\
70\end{array}$ & $\begin{array}{l}50 \\
76 \\
68 \\
35 \\
35 \\
80 \\
40 \\
35 \\
40 \\
70 \\
49 \\
40 \\
22 \\
43 \\
\frac{25}{70}\end{array}$ & $\begin{array}{l}35 \\
35 \\
60 \\
35 \\
40 \\
50 \\
28 \\
23 \\
40 \\
45 \\
40 \\
27 \\
22 \\
43 \\
54 \\
40 \\
28\end{array}$ \\
\hline Mean & 1459 & - & $4 \cdot 8$ & $15 \cdot 6$ & $24 \cdot 4$ & $12 \cdot 1$ & $36 \cdot 3$ & $48 \cdot 6$ & $37 \cdot 9$ \\
\hline
\end{tabular}


Immunoglobulin $A$ and $M$ Levels in Premature Infants with Gastroenteritis

TABLE III

Diarrhoea Group: Immunoglobulin $A$ and $M$ Levels in Infected Group of Prematures

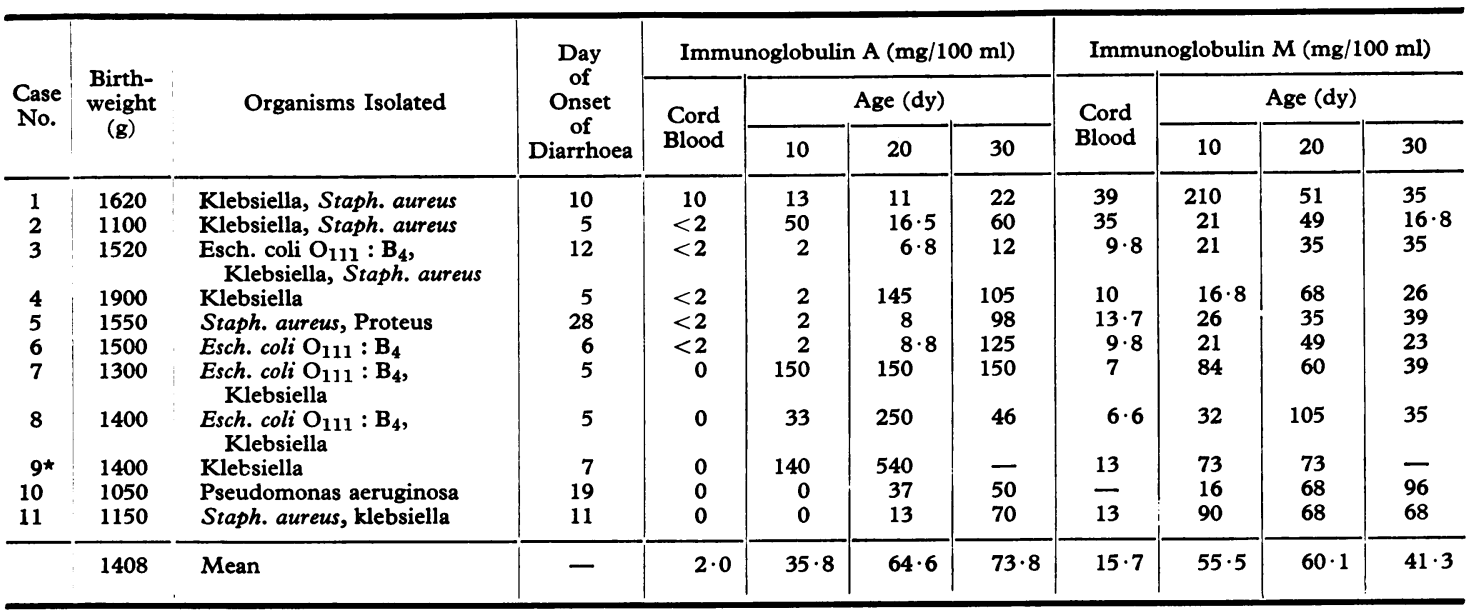

* Died at the age of 24 days. IgA values were excluded from the statistical analysis and the estimation of the mean.

One baby (Case 7) with undetectable IgA values at birth, showed a sharp increase of IgA to $150 \mathrm{mg} /$ $100 \mathrm{ml}$ after developing diarrhoea at the age of 5 days. One infant (Case 9) with very severe gastroenteritis died at 24 days. Stool cultures revealed klebsiella, while blood cultures remained sterile. Levels of IgA in this premature were high $(140 \mathrm{mg}$ at age 10 days and $540 \mathrm{mg} / 100 \mathrm{ml}$ at age 20 days).

Mean IgA levels of all patients at ages 10, 20, and 30 days were $35 \cdot 8,64 \cdot 6$, and $73 \cdot 8 \mathrm{mg} / 100 \mathrm{ml}$, respectively (Table III).

Two infants (Cases 1 and 2) had high IgM values at birth. There was no history of maternal disease or infection during pregnancy and both babies were considered healthy. As in babies of the healthy group, IgM levels in infected prematures showed inconsistent fluctuations with advancing

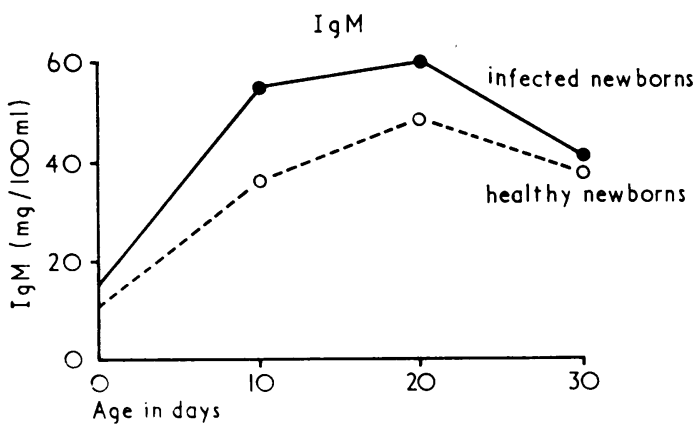

Fig. 1.-Fluctuations of IgM levels in infected and healthy prematures. age. Mean IgM value at birth was $15 \cdot 7 \mathrm{mg} / 100 \mathrm{ml}$ while at age 10,20, and 30 days it was $55 \cdot 5,60 \cdot 1$, and $41.3 \mathrm{mg} / 100 \mathrm{ml}$, respectively. Each of the above measurements is higher but not significantly so $(P>0 \cdot 1)$ from the corresponding IgM mean value of the healthy group (Fig. 1).

On the contrary, IgA levels in the diarrhoea group are significantly $(P<0.05)$ higher in all measurements $(t=2.24, P<0.05$ on the 10th day $t=$ $2.37, P<0.05$ on the 20th day, and $t=4.4$ $P<0.001$ on the 30th day) (Fig. 2). Case 9 died and, having presented an exceptionally high level of $\mathrm{IgA}(540 \mathrm{mg} / 100 \mathrm{ml})$ at the age of 20 days, was excluded from the statistical analysis.

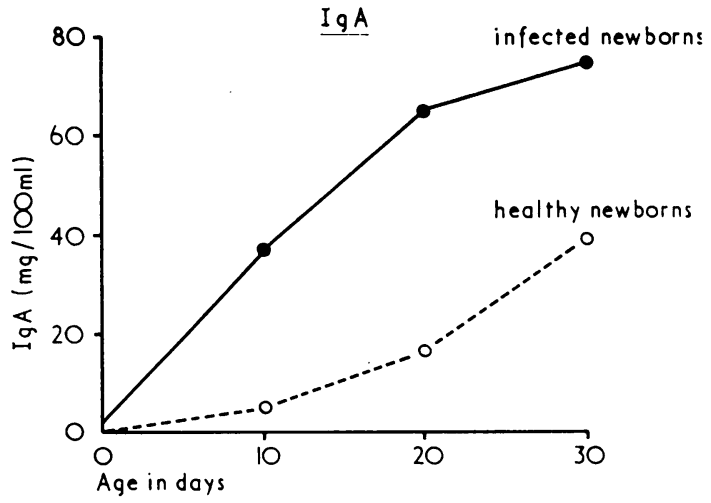

FIG. 2.-Fluctuations of Ig $A$ levels in infected and healthy prematures. 


\section{Discussion}

It has already been reported that in a number of acute infections, abnormal increases in immunoglobulin $M$ furnish confirmatory diagnostic information (Blankenship et al., 1969; Korones et al., 1969). It should be stressed, however, that a high incidence of immunoglobulin 'non-reactivity' is seen in sera of infants who die of an infection shortly after birth (Blankenship et al., 1969). Furthermore, in a number of term or premature infants with no obvious clinical signs of maternal or neonatal disease, IgM levels at birth are raised. A similar trend has been observed in our material of infected premature babies in which differences in mean IgM values were not significant from mean values of the healthy group.

In healthy newborns an increase of IgM soon after birth in a gradual or sharp incline is noted, and by the 30th day of life a frequent decrease in mean IgM levels has been recently described (Alford et al., 1968; Allansmith, McClellan, and Butterworth, 1969). 9 of our 17 healthy prematures showed a similar immunoglobulin $M$ pattern. This decrease of $\operatorname{IgM}$ at the age of 30 days could be considered as evidence of early IgG synthesis. It has already been suggested that the increase of IgG, which is well established by the first month of life, shuts off some of the IgM synthesis (Sahiar and Schwartz, 1964).

The major antibody class on all body surfaces is secretory immunoglobulin $A$, and cells producing IgA have been shown in the intestinal mucosa (Crabbé, Carbonara, and Heremans, 1965). Keller et al. (1969) have shown that in infants of 4 to 6 weeks, faecal IgA concentration already approached adult levels and was present in the faeces of some infants even in the absence of detectable serum IgA.

These results support, according to these authors, the concept of local antibody synthesis and suggest that the intestinal antibody system responds rapidly to local antibody stimulation resulting from the acquisition of the intestinal bacterial flora. This concept is further supported by the work of Ogra et al. (1968) who reported the presence of IgA polio-virus antibodies from nasal and duodenal secretions after oral polio-virus immunization.

The studies of this report used premature babies to evaluate the immunological response to a localized infection. The results indicate that the bacterial antigenic stimulus experienced by the premature baby has a direct influence on total serum IgA levels and to a less and not significant degree on IgM levels. As a result of a gastrointestinal tract infection, the IgA increase could be interpreted as follows. Bacterial pathogens causing a gastroenteritis of the premature baby stimulate directly the immunoglobulin A producing sites of the gastrointestinal tract. This stimulation is followed by rapid production of secretory antibody. In the course of the localized infection, replication of bacteria in the lymphoid tissue of the intestinal wall acts as a potent stimulus to immunologically competent cells in direct juxtaposition to the alimentary tract resulting in increased serum IgA levels. A similar replication in lymphoid cells of the pharyngeal and intestinal walls causing increased IgA synthesis has already been noted in polio-virus infections by Crabbé et al. (1965) and Bodian and Horstmann (1965).

Our results suggest that the secretory immunoglobulin A system of the gastrointestinal tract is not absolutely independent from the 'humoral' system responsible for circulating antibodies.

\section{REFERENCES}

Alford, C., Blankenship, W., Straumfjord, J., and Cassady, G. (1968). The diagnostic significance of IgM globulin elevations in newborn infants with chronic intrauterine infections. In Birth Defects Original Article Series, vol. IV, p. 3. Ed. by D. Bergsma. National Foundation, New York.

Allansmith, M. R., McClellan, B. H., and Butterworth, M. (1969). Individual patterns of immunoglobulin development in ten infants. Fournal of Pediatrics, 75, 1231.

Blankenship, W. J., Cassady, G., Schaefer, J., Straumfjord, J. V., and Alford, C. A., Jr. (1969). Serum gamma-M globulin. responses in acute neonatal infections and their diagnostic significance. Fournal of Pediatrics, 75, 1271.

Bodian, D., and Horstmann, D. M. (1965). Polioviruses. In Viral and Rickettsial Infections of Man, 4th ed., p. 430. Ed. by F. L. Horsfall, Jr., and I. Tamm. Lippincott, Philadelphia; Pitman, London.

Crabbé, P. A., Carbonara, A. O., and Heremans, J. F. (1965). The normal human intestinal mucosa as a major source of plasma cells containing gamma-A-immunoglobulin. Laboratory Investigation, 14, 235.

Keller, R., Dwyer, J. E., Oh, W., and D'Amodio, M. (1969). Intestinal IgA neutralizing antibodies in newborn infants following poliovirus immunization. Pediatrics, 43, 330.

Kim, Y. B., Bradley, S. G., and Watson, D. W. (1966). Ontogeny of the immune response. Development of immunoglobulins in germfree and conventional colostrum-deprived piglets. fournal of Immunology, 97, 52.

Korones, S. B., Roane, J. A., Gilkeson, M. R., Lafferty, W., and Sever, J. L. (1969). Neonatal IgM response to acute infection. Fournal of Pediatrics, 75, 1261.

McCracken, G. H., and Shinefield, H. R. (1965). Immunoglobulin concentrations in newborn infants with congenital cytomegalic inclusion disease. Pediatrics, 36, 933.

Mancini, G., Carbonara, A. O., and Heremans, J. F. (1965). Immunochemical quantitation of antigens by single radial immunodiffusion. Immunochemistry, 2, 235.

Ogra, P. L., Karzon, D. T., Righthand, F., and MacGillivray, M. (1968). Immunoglobulin response in serum and secretions after immunization with live and inactivated poliovaccine and natural infection. New England fournal of Medicine, 279, 893.

Olson, G. B., and Wostman, B. S. (1966). Lymphocytopoiesis plasmatocytopoiesis and cellular proliferation in nonantigenically stimulated germ-free mice. Fournal of Immunology, 97, 267.

Sahiar, K., and Schwartz, R. S. (1964). Inhibition of $19 S$ antibody synthesis by $7 \mathrm{~S}$ antibody. Science, 145, 395. 
Sterzl, J., and Silverstein, A. M. (1967). Developmental aspects of immunity. Advances in Immunology, 6, 337.

Stiehm, E. R., Ammann, A. J., and Cherry, J. D. (1966). Elevated cord macroglobulins in the diagnosis of intrauterine infections. New England fournal of Medicine, 275, 971.

Tomasi, T., and Galvanico, N. (1968). Human secretory gamma-A. Federation Proceedings, 27, 617.
Wostman, B. S., and Gordon, H. A. (1960). Electrophoretic studies on the serum protein pattern of the germ free rat and its changes upon exposure to a conventional bacterial flora. fournal of Immunology, 84, 27.

Correspondence to Dr. C. Papadatos, Alexandra Maternity Hospital, Athens (611), Greece. 